the nab. Preliminary work shows that: $(a)$ Each of the 24 samples of different wools which were visually appraised as 'doggy' contained many fibres with nabs on them. (b) Each of the 120 single fibres selected visually as 'doggy' had nabs on it. (c) Nabs were found on a few fibres from normal wool staples, but every such fibre was judged visually as 'doggy'. (d) No nabs were found on 100 steely (copper defieient) wool fibres; these fibres are straight and are sometimes confused with 'doggy' fibres. (e) There were about 50 nabs in $6.5 \mathrm{~cm}$ of typical 'doggy' wool; the range was from 10 to 140 nabs for the 100 fibres examined. $(f)$ The 'doggier' the fibre the more nabs on it. $(g)$ 'Doggy' fibres are not entirely straight; there are occasional curved portions in the unconstrained fibre. Three-quarters of the nabs were on the straight parts of the 50 fibres examined for this effect. (h) The modal periodicity of nabs was between 250 and 300 microns, which corresponds roughly to one day's growth of wool fibre.

It has been shown $n^{3,8}$ that on follicles growing 'doggy' wool fibres there are cysts close to the outer root sheath at or below the zone of keratinization. If the follicles oscillate under the action of arrector pili muscles the bulb of a follicle may be pressed against a cyst. The pressure of a cyst on the soft fibre before keratinization would account for the shape of the nabs. Continued oscillation would separate cyst and follicle, thus giving an interval of normal wool growth. The periodicity of nabs along 'doggy' wool fibres fits in roughly with the growth rate needed for this cycle of events.

$$
\text { J. F. P. JAMES }
$$$$
\text { D. J. WARD }
$$

C.S.I.R.O. Wool Research Laboratories,

Division of Textile Physics,

Ryde, Sydney,

Australia.

${ }^{1}$ Australian Wood Board, Statistical Analysis No. 41 (Sept., 1963).

${ }^{2}$ Lang, W. R., and Sweetten, R. B., J. Text. Inst., 51, T922 (1960).

'Chapman, R. F., Short, B. F., and Hyland, P. G., Nature, 187, 960 (1960).

- Goldsworthy, Y. E., and Lang, W. R., J. Text. Inst., 45, T755 (1954).

'Aiken, J. D., and Ryder, M. L., Austral. J. Science, 24, 484 (1962).

'James, J. F. P., Nature, 198, 1112 (1963).

' James, J. F. P., J. Text. Inst., 54, T420 (1963).

"Chapman, R. E., thesis, University of New South Wales (1962).

\section{Two Polyzoans new to the British Fauna}

TrawLERMEN fishing off St. Kilda during the summer of 1964 reported the presence of large quantities of 'weed'. A sample obtained in June was examined and found to consist mainly of hydroids and erect branching polyzoans bound up among shell detritus and argillaceous matter. The Polyzoa present were identified, and among them were two species not previously recorded from British waters: Bicrisia abyssicola Kluge and Sertella septentrionalis Harmer.

Bierisia abyssicola has previously been found only off the coast of Norway ${ }^{1,2}$. Being the only European species of Bicrisia, identification presents no problem. It has been briefly described by Ryland ${ }^{1}$ and is figured by Kluge $^{2}$.

Sertella septentrionalis has a mainly Arctic-Boreal distribution, though what is apparently the same species has been reported from the Azores and is not uncommon in the Mediterranean ${ }^{3}$. A description is given by Gautier ${ }^{3}$ and a figure, under the name Retepora cellulosa, by Kluge ${ }^{2}$.

Two other species of Sertella were found in the sample: $S$. beaniana (King) is a common northern form; but $S$. couchii (Hincks) has a Mediterıanean-Lusitanean distribution, and the present record constitutes the most northerly known. The occurrence of both southern and boreal species is a characteristic feature of the polyzoan fauna of the Hebrides ${ }^{1,4}$. The remaining species recorded were all characteristic of Atlantic habitats in north-west Europe, the celleporan Harmerella dichotoma (Hincks) being particularly common.

\section{J. S. RYLAND}

Fisheries Laboratory, Lowestoft.

${ }^{1}$ Ryland, J. S., Sarsia, 14, 1 (1963).

${ }^{2}$ Kluge, G. A., Tabl.:Anal. Faune V.R.S.S., 76, 1 (1962).

${ }^{3}$ Gautier, Y. V., Rec. Trav. Sta, Mar. Endoume, 38, 1 (1962).

${ }^{4}$ Ryland, J. S., Seot. Nat., 71, 13 (1963).

\section{ENTOMOLOGY}

\section{Protective Display and Underwing Cryptic Markings in an East African Saturnioid}

The normal daylight position of rest in many species of saturnioid is with the wings outstretched and the forewings folded back so as to cover the vivid hind-wing eye spots and their surrounding field of colour, leaving the remaining part of the hind-wings exposed to view. Cryptic coloration of the fore-wings and the exposed parts of the hind-wings is usually sufficiently well developed to ensure a measure of protection from predators when the insect is at rest either on bark or among dead leaves and woodland debris. The exposed fore-wing fenestrae with their yellow or brown edges simulate equally well algae and lichen on bark, or mould marks on dead leaves.

That some moths do exercise a certain degree of selectivity in choosing the background on which to rest during the day has been shown by the experiments of Kettlewell ${ }^{2}$. Similarly, Seitz ${ }^{2}$ noted that the saturnioid Nudaurelia wahlbergi Boisd. shows a marked preference for the bases of tree trunks and dead leaf litter for its day resting. place, in both of which its yellow-brown eryptic upperwing markings would be of advantage in concealment. The present observations also indicate that many saturnioids are to be found in these sites. This may be a measure of the ease of accessibility to the observer rather than to a preference of the moths for such sites. A record, however, of the resting positions of newly reared Nudaurelia gueinzii Karsch in flight cages suggests (Table 1) that flat surfaces are favoured over twigs and leafy branches, with a definite preference for the leaf-litter-strewn cage floor.

Table 1. DaY Resting SITES of $N$. gueinzii. NUMbers REPRESENT INDIVIDUALS SCORED ONCE ON SECOND DAY AFTER EMERGENCE

\begin{tabular}{|c|c|c|c|}
\hline & $\begin{array}{l}\text { Littered cage } \\
\text { floor }\end{array}$ & $\begin{array}{c}\text { Gauze cage } \\
\text { sides }\end{array}$ & $\begin{array}{l}\text { Twigs and } \\
\text { branches }\end{array}$ \\
\hline No. moths & 41 & 30 & 16 \\
\hline
\end{tabular}

A feature of many saturnioids, however, is the high degree of development of cryptic coloration on the underside of the wings. Light and dark shading and coincident wing markings are often much more developed than on the upper side. Several species show, when the wings are at rest, a striking similarity on the underside to a dead leaf with constructive shading of coincident wing markings ${ }^{3}$ giving an impression of false relief to the flat wing surfaces. The body is usually plainly coloured and may be countershaded. Leaf mid-rib patterns may be indicated while the fore-wing and hind-wing fenestrae simulate mould marks. There is no trace of any eye spots which may be present on the upper side of the hind-wings, that is, the whole of the underside wing pattern is one of concealment only. This would suggest that at some time in the lives of moths so marked, but with a seeming preference for resting on flat surfaces, there may be occasion to rest with the ventral side prodominantly exposed to view and that in this position the degree of leaf resemblance is of selective value for survival.

A possible partial explanation of this development is seen in the protective and alarm display of $N$. gueinzii, 